\title{
MALIGNANT FIBROUS HISTIOCYTOMA IN ASSOCIATION WITH HIP REPLACEMENT
}

\author{
M. HAAG, C. P. ADLER
}

In 1975 a 69 -year-old woman with severe osteoarthritis of the left hip was treated by a cemented total hip replacement. A year earlier the same procedure had been performed on the right hip. Both implants were of Weber-Huggler type II and were fixed with PMMA bone cement (Sulfix). The cup of this type of prosthesis is made of polyethylene, the stem of Protasul 10, containing chromium, nickel and cobalt.

The patient was well for some years, but nine years after the hip replacement she gradually developed pain in the left thigh on taking weight, and a year later came back to hospital.

Radiographs showed loosening of the stem, explaining the patient's discomfort; there was also a suspicion of osteolysis of the lesser trochanter (Fig. 1). A ${ }^{99} \mathrm{Tc}$ bone scan showed marked increase in uptake in the same region. The ESR was raised, but attempted aspiration of the hip to exclude infection proved negative.

At operation we were surprised to find a tumour which was clearly malignant; it was greyish-red in colour and had partially destroyed the upper end of the femur. The tumour had invaded the interface between bone and cement, the entire bone circumference was eroded and on its medial aspect the bone was perforated. The stem was completely loose and the cement could be extracted in one piece. At the site of bone perforation the muscles were infiltrated.

Histologically a fast-frozen section revealed a malignant bone tumour, so $10 \mathrm{~cm}$ of the upper end of the femur was resected and a specially designed prosthesis implanted. She was given radiotherapy, but six months later she died with multiple metastases.

The definitive histology investigations showed a typical malignant fibrous histiocytoma. The medullary trabeculae were largely destroyed, the remaining bone trabeculae had uneven outlines and bone destruction by the tumour could be seen.

Discussion. We have seen very few reports of malignant tumours at the site of a prosthesis (Table I). It is noteworthy that one of these was at the site of an

M. Haag, MD. Senior Orthopaedic Registrar

C. P. Adler, MD, Professor of Pathology

Department of Orthopaedic Surgery and the Institute of Pathology University of Freiburg. Hugstetter Str. 55. D-7800. Freiburg, West Germany

Correspondence to $\mathrm{Mr} \mathrm{M}$. Haag.

(C) 1989 British Editorial Society of Bone and Joint Surgery $0301-620 \mathrm{X} / 89 / 4 \mathrm{R} 22 \$ 2.00$

J Bone Joint Surg [Br] 1989:71-B:701
Table I. Published reports of malignant fibrous histiocytoma (MFH)

\begin{tabular}{lll}
\hline Author & Histology & Implant \\
\hline Bagò-Granell et al 1984 & MFH & Müller-Charnley \\
Swann 1984 & MFH & McKee-Farrar \\
Penman and Ring 1984 & Osteosarcoma & Ring* \\
Weber 1986 & $\begin{array}{l}\text { Epitheloid sarcoma or } \\
\text { MFH or fibrosarcoma }\end{array}$ & $\begin{array}{l}\text { Variable axis knee } \\
\text { prosthesis }\end{array}$ \\
Haag and Adler 1989 & MFH & Weber-Huggler \\
\hline
\end{tabular}

* this was the only uncemented prosthesis

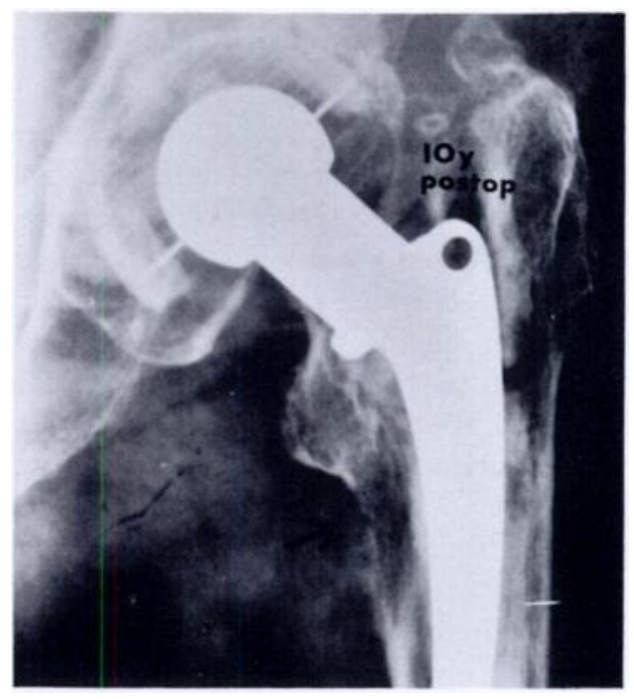

Fig. 1

uncemented prosthesis. In recent years malignant fibrous histiocytoma, formerly a rare tumour, has been reported much more frequently, particularly as a soft-tissue tumour of the lower limbs in older men. Though the number of reported tumours is extremely small compared with the great number of arthroplasties performed, it seems possible that the coincidence is not accidental.

The authors chose not to respond to the request for a conflict of interest statement.

\section{REFERENCES}

Bagò-Granell J, Aquirre-Canyadell M, Nardi J, Tallada N. Malignant fibrous histiocytoma of bone at the site of a total hip arthroplasty: a case report. J Bone Joint Surg [Br] 1984;66-B:38-40.

Penman HG, Ring PA. Osteosarcoma in association with total hip replacement. J Bone Joint Surg [Br] 1984;66-B :632-4.

Swann M. Malignant soft-tissue tumour at the site of a total hip replacement. J Bone Joint Surg [Br] 1984 ;66-B :629-31.

Weber PC. Epithelioid sarcoma in association with total knee replacement. J Bone Joint Surg [Br] 1986;68-B :824-6. 